\title{
Complex Compound with Transitional Metal of Akway Bark (Drimys piperita Hook F.) as Low Molecular Weight Scavenging Antioxidant: A Computational Study
}

\author{
Hostalige Hutasoi t ${ }^{1}$, Dionysius Joseph Djoko Herry Santjojo ${ }^{2}$, Sutiman Bambang Sumitro ${ }^{3}$, Simon \\ Bambang Widjanarko *1 \\ ${ }^{1}$ Department of Food Science and Technology, Faculty of Agricultural, Brawijaya University, Malang 65145, \\ Indonesia \\ ${ }^{2}$ Department of Physics, Faculty of Mathematics and Natural Science, Brawiaya University, Malang 65145, \\ Indonesia \\ ${ }^{3}$ Department of Biology, Faculty of Mathematics and Natural Science, Brawijaya University, Malang 65145, \\ Indonesia
}

\section{Article history:}

Submission September 2020

Revised September 2020

Accepted May 2021

*Corresponding author:

E-mail: simonbw@ub.ac.id

\begin{abstract}
Akway (Drimys piperita Hook f.) was known as an endogenous plant of Indonesia. This plant was investigated as a free radical scavenger based on paramagnetic properties. This study aimed to identify the bioactive compound and the role of Fe metals ions to enhance the free radical scavenger capacity as Low molecular weight antioxidant (LWMA) of akway. This study was designed by ultra-performance liquid chromatography (UPLC) coupled with ultra-high-resolution time of flight-mass spectrometry detector (TOF-MS), docking (Pyrex and Discovery Studio 2016 Client) and pharmacokinetic properties prediction (SwissADME). UPLC-TOF-MS analysis showed that herbal akway bark has five molecular formula $\left(\mathrm{C}_{4} \mathrm{H}_{3} \mathrm{~N}_{10} \mathrm{O}_{2}{ }^{1-}, \mathrm{C}_{14} \mathrm{H}_{19} \mathrm{~N}_{4} \mathrm{O}_{9}{ }^{1-}\right.$, $\mathrm{C}_{4} \mathrm{H}_{7} \mathrm{~N}_{6} \mathrm{O}_{5}{ }^{1-}, \mathrm{C}_{15} \mathrm{H}_{28} \mathrm{NO}_{3}{ }^{1+}$, and $\mathrm{C}_{23} \mathrm{H}_{32} \mathrm{NO}_{7}{ }^{1+}$ ). The docking was illustrated the complex binding akway formula with $\mathrm{Fe}$ and its role as a metal donor and metal acceptor. It also confirmed on pharmacokinetics properties prediction which molecular compounds of akway have aqueous solubility. It meant the herbal akway bark complexed to Fe could be a low molecular weight antioxidant and it could be escalated free radical scavenger capacity.
\end{abstract}

Keywords: Akway, Antioxidant, Endogenous plant, Herbal medicine, Metal acceptor, Metal donor, Molecular formula

\section{Introduction}

A free radical scavenger or antioxidant is a molecule adequate for decreasing or inhibiting the other molecule's oxidation. Oxidation transfer electron from a substance to an agent of oxidation [1]. At the same time, free-radicals are produced subsequently start chain reactions to decay the animal cells. Antioxidants have delayed this reaction by eliminating free radical agents and inhibiting other oxidation reactions by oxidizing themselves $[2,3]$. Antioxidants are compounds with various molecular and chemical structures and are either lipid (hydrophobic) or water-soluble (hydrophi- lic). They are either synthesized within the human body or are admitted within food and beverage [4].

Akway (Drimys piperita Hook f.) is a woody plant that contains aromatic compounds. This plant is originated from Pegunungan Arfak District, West Papua, Indonesia. Akway bark was locally used Sougb tribe to boost vitality by boiling the bark into the water and drink it as a herbal beverage $[5,6]$. Based on previous research on phytochemical screening, extracts of akway contained several bioactive compounds such as alkaloids, flavonoids, glycoside, tannins, and saponins [7]. The preliminary research was done to investigate

\section{How to cite:}

Hutasoit H, Santjojo DJDH, Sumitro SB, Widjanarko SB (2021) Complex compound with transitional metal of Akway Bark (Drimys piperita Hook f.) as low molecular weight scavenging antioxidant: a computational study. Journal of Tropical Life Science 11 (3): 267 - 273. doi: 10.11594/jtls.11.03.02. 
the paramagnetic properties of akway as a free radical scavenger. It was showed ease of DPPH free radical activity following an addition of akway bark by electron spin resonance (ESR) analysis. Complex akway-DPPH (as free radical agent) compared to DPPH indicated a decrease in the resonance curve. Akway bark as an herbal medicine was found could be a radical scavenger that reduces unpaired DPPH electron [6].

Therefore, identifying akway's small molecules is important for continuing the bioinformatics study and their effects as antioxidants or free radical scavengers. Under these conditions, ultraperformance liquid chromatography (UPLC) coupled with time-of-flight mass spectrometry (QTOF-MS/MS) accommodates appropriate structural information about the bioactive compounds for the separation and identification of complex mixtures $[8,9,10]$.

Low molecular weight antioxidant (LWMA) complex is an active compound in herbal medicine with the role as a radical scavenger. It is known in bioinorganic chemistry, which contained metal ions such as $\mathrm{Fe}, \mathrm{Cu}, \mathrm{Zn}$, and $\mathrm{Mn}$ and promised pharmaceutical agents. In the complex compound of plant, LWMA is free from a physical and chemical bond with other macromolecules [11, 12, 13]. The LMWA either bond as a part of endogenic enzymes in cellular metabolism or LMWA themselves by other protein components containing transition metal. Side by protein, non-nutrient like phenolic compounds (flavonoid, alkaloid, phenolic acid, and lignans) could regulate the free radicals by inhibiting it from catching in Haber-Weiss reaction [11, 14, 15].

Research related to akway has not been completed. Bioinformatics study becomes the base of this research to identify the bioactive compound of akway (D. piperita Hook f.) and the role of Fe metals ions to enhance the free radical scavenger capacity of akway.

\section{Material and Methods Preparation of Akway bark}

Fresh harvested Akway (D. piperita Hook f.) bark samples were collected from Pegunungan Arfak district, Manokwari, West Papua, Indonesia. It was air-dried at room temperature $\left(25^{\circ} \mathrm{C}\right)$ for 24h. After that, $1000 \mathrm{~g}$ of akway bark was milled to form a powder. The powder was then boiled to $100^{\circ} \mathrm{C}$ for 15 minutes using water at the ratio of solid : water at $1: 5$. The suspension was sonicated for $30 \mathrm{~min}$ and freeze-dried, then stored in the freezer.

\section{Identify of bioactive compound}

An ultra-performance liquid chromatography (UPLC) coupled with ultra-high-resolution time of flight-mass spectrometry detector (TOF-MS) (Eppendorf, Jerman) assay was conducted for the identification of bioactive compound which contained on freeze-dried suspension [16]. Chromatographic separations were performed with mobile phase RSLC 120 C18 $(2.2 \mu \mathrm{m} ; 120 \AA 2.1 \times 100$ mm, Eppendorf, Jerman). The pump was associated with a gradient binary solvent system: Methanol $10 \%$ with $5 \mathrm{mM}$ ammonium acetate (A) and Methanol with $5 \mathrm{mM}$ ammonium acetate (B). The mobile phase was arranged consecutively in a linear gradient as follows: $0-1 \mathrm{~min}, 99 \% \mathrm{~A}$ and $1 \%$ B; 3 min, $61 \%$ A and 39\% B; $14-16$ min, $1 \%$ A and $99 \% \mathrm{~B}$; and $16.1-20 \mathrm{~min}, 99 \% \mathrm{~A}$ and $1 \% \mathrm{~B}$. The ionization source was performed with electrospray ionization (ESI) to acquire mass spectra and scanning range $50-1000 \mathrm{~m} / \mathrm{z}$ in positive and negative modes. UPLC-TOF-MS has obtained the molecular formula and their mass-to-charge ration $(\mathrm{m} / \mathrm{z})$ of akway bark.

\section{Computational modeling}

Prediction of metal-compound interaction is essential for the success of computational approaches. Molecular docking was well known as computational modeling that aims to predict the demanded orientation of a ligand to its receptor when these are bind to each component to establish a stable complex material [17]. The molecular formula of akway bark was confirmed to the PubChem database and was found the 2D structure (Table 1). It was docked with the Fe molecule (CID: 27284) to evaluate how the metal transition was to enhance the antioxidant properties of akway bark. Docking site and conformational properties were analyzed using Pyrex and Discovery Studio 2016 Client $[18,19]$. Docking was run by entering the molecular formula of akway bark and Fe molecule to Pyrex. Subsequently, it was analyzed by Discovery Studio 2016 Client to comprehend the molecular structure, binding affinity, and prove the role of Fe molecule to akway bark component as low molecular weight antioxidant. The docking process was well done by AutoDock Vina using the different vina search box (Table 1). 
Table 1. The molecular formula of akway bark by UPLC-TOF-MS confirmed to PubChem

\begin{tabular}{|c|c|c|c|c|c|c|}
\hline No. & $\begin{array}{l}\text { Retention } \\
\text { Time } \\
\text { (min) }\end{array}$ & $\begin{array}{c}\text { Identified Mo- } \\
\text { lecular For- } \\
\text { mula }\end{array}$ & $\mathrm{m} / \mathrm{z}$ & $\begin{array}{l}\text { Intensity } \\
\text { (a.u.) }\end{array}$ & 2D Structure & $\begin{array}{c}\text { PubChem } \\
\text { CID }\end{array}$ \\
\hline 1. & 1.21 & $\mathrm{C}_{4} \mathrm{H}_{3} \mathrm{~N}_{10} \mathrm{O}_{2}{ }^{1-}$ & 223.0446 & $2.9 \times 10^{4}$ & & 136877171 \\
\hline 2. & 1.34 & $\mathrm{C}_{14} \mathrm{H}_{19} \mathrm{~N}_{4} \mathrm{O}_{9}{ }^{1-}$ & 387.1158 & $3.1 \times 10^{4}$ & & 78168764 \\
\hline 3. & 1.34 & $\mathrm{C}_{4} \mathrm{H}_{7} \mathrm{~N}_{6} \mathrm{O}_{5}{ }^{1-}$ & 219.0483 & $4.1 \times 10^{4}$ & & 101674670 \\
\hline 4. & 7.07 & $\mathrm{C}_{15} \mathrm{H}_{28} \mathrm{NO}_{3}{ }^{1+}$ & 270.2064 & $2.0 \times 10^{5}$ & & 171502 \\
\hline 5. & 10.3 & $\mathrm{C}_{23} \mathrm{H}_{32} \mathrm{NO}_{7}{ }^{1+}$ & 434.2173 & $2.3 \times 10^{4}$ & & 91539162 \\
\hline
\end{tabular}

It was enhanced to virtual-screen the optimized docking site of Fe binds to akway bark compounds [20]. Then, the pharmacokinetics properties, included physicochemical and water solubility of akway bark's molecular formulas, were analyzed using SwissADME (http://www.swissadme.ch/) [21].

\section{Results and Discussions}

Akway bark is a potential source of natural, free radical scavenger, as has been done in previous research. As a result, java plum (Syzygium cumini) and mangosteen (Garcinia mangostana Linn.) rind extract were unambi-guously identified and assigned as antioxidant sources. Java plum extract was contained a metal transition complex with anthocyanin, while mangosteen rind extract was included in xanthone which showed a declining resonance curve of electron spin resonance. Additionally, free radical java plum and mangosteen rind extract intensity decreased [13, 22]. UPLC-TOF-MS has been validated and evolved as a current chromatographic analysis to identify and determine substances in complex ma- 

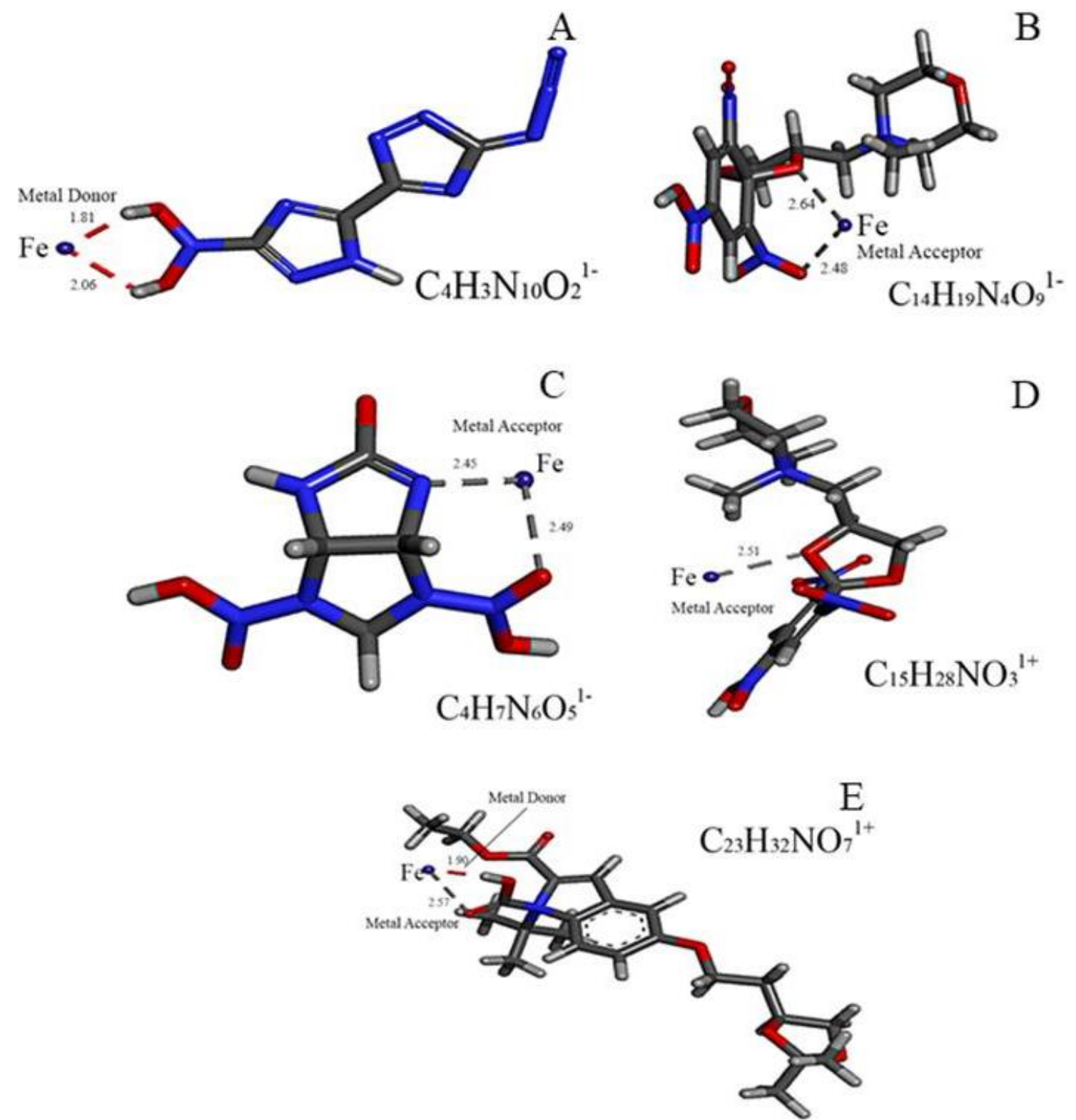

Figure 1. Variabilities of possible complex structures with Fe: $\mathrm{C}_{4} \mathrm{H}_{3} \mathrm{~N}_{10} \mathrm{O}_{2}{ }^{1-}(\mathrm{A}) ; \mathrm{C}_{14} \mathrm{H}_{19} \mathrm{~N}_{4} \mathrm{O}_{9}{ }^{1-}(\mathrm{B}) ; \mathrm{C}_{4} \mathrm{H}_{7} \mathrm{~N}_{6} \mathrm{O}_{5}{ }^{1-}$ (C); $\mathrm{C}_{15} \mathrm{H}_{28} \mathrm{NO}_{3}{ }^{1+}$ (D) and $\mathrm{C}_{23} \mathrm{H}_{32} \mathrm{NO}_{7}{ }^{1+}$ (D)

terials [23, 8]. In this study, based on the UPLCTOF-MS analysis, we were discovered potential bioactive formulas as a precursor and fragment site, and subsequently, it screened to PubChem database. According to Table 1, there were five molecular formulas identified by UPLC-TOF-MS. The molecular formula that appeared are a molecular formula with a high $\mathrm{m} / \mathrm{z}$ value and a peak intensity at a particular retention time. The molecular formulas have not been identified as specific compounds. However, the molecular formula data by UPLC-TOF-MS become the determinant for data mining in the PubChem database, so the bioinformatics study could be carried out.
Docking was showed an interaction between $\mathrm{Fe}$ and the molecular formula(s). The $\mathrm{C}_{4} \mathrm{H}_{3} \mathrm{~N}_{10} \mathrm{O}_{2}{ }^{1}$, $\mathrm{C}_{14} \mathrm{H}_{19} \mathrm{~N}_{4} \mathrm{O}_{9}{ }^{1-}, \quad \mathrm{C}_{4} \mathrm{H}_{7} \mathrm{~N}_{6} \mathrm{O}_{5}{ }^{1-}, \quad \mathrm{C}_{15} \mathrm{H}_{28} \mathrm{NO}_{3}{ }^{1+}$, and $\mathrm{C}_{23} \mathrm{H}_{32} \mathrm{NO}_{7}{ }^{1+}$ has a number of binding affinity -0.4 ; -0.6 ; -0.6; -0.6, - $-0.4 \mathrm{kcal} / \mathrm{mol}$, respectively. Based on Figure 1, there are Fe (orbicular blue) and crystal structures molecular formula. The type of bond between a metal and molecular formula is metal donor and metal acceptor. $\mathrm{C}_{4} \mathrm{H}_{3} \mathrm{~N}_{10} \mathrm{O}_{2}{ }^{1-}$ has two metal donor site $1.81 \AA$ and $2.06 \AA$. Subsequently, $\mathrm{C}_{14} \mathrm{H}_{19} \mathrm{~N}_{4} \mathrm{O}_{9}{ }^{1-}, \mathrm{C}_{4} \mathrm{H}_{7} \mathrm{~N}_{6} \mathrm{O}_{5}{ }^{1-}$, and $\mathrm{C}_{15} \mathrm{H}_{28} \mathrm{NO}_{3}{ }^{1+}$ have metal acceptor sites: $2.64 \AA$ and $2.48 \AA ; 2.45 \AA$ and 2.49 $\AA 2.51 \AA$, respectively. Only $\mathrm{C}_{23} \mathrm{H}_{32} \mathrm{NO}_{7}{ }^{1+}$ has a metal donor site $1.90 \AA$ and a metal acceptor site 
Table 2. Prediction of Pharmacokinetics Properties akway bark’s molecular formula by SwissADME software (http://www.swissadme.ch/)

\begin{tabular}{|c|c|c|c|c|c|c|}
\hline \multirow{2}{*}{ No. } & \multirow{2}{*}{$\begin{array}{l}\text { Pharmacokinetics } \\
\text { Properties }\end{array}$} & \multicolumn{5}{|c|}{ Molecular Formula of akway bark (Drymis piperita Hook f.) } \\
\hline & & $\mathrm{C}_{4} \mathrm{H}_{3} \mathrm{~N}_{10} \mathrm{O}_{2}$ & $\mathrm{C}_{14} \mathrm{H}_{19} \mathrm{~N}_{4} \mathrm{O}_{9}$ & $\mathrm{C}_{4} \mathrm{H}_{7} \mathrm{~N}_{6} \mathrm{O}_{5}$ & $\mathrm{C}_{15} \mathrm{H}_{28} \mathrm{NO}_{3}$ & $\mathrm{C}_{23} \mathrm{H}_{32} \mathrm{NO}_{7}$ \\
\hline 1. & Molecular weight (g/mol) & 223.13 & 387.32 & 219.14 & 270.39 & 434.50 \\
\hline 2. & Num. heavy atoms & 16 & 27 & 15 & 19 & 31 \\
\hline 3. & Num. arom. heavy atoms & 5 & 0 & 0 & 0 & 6 \\
\hline 4. & Fraction Csp3 & - & 0.64 & 0.75 & 0.87 & 0.57 \\
\hline 5. & Num. rotatable bonds & 2 & 4 & 2 & 13 & 9 \\
\hline 6. & Num. H-bond acceptors & 10 & 9 & 6 & 3 & 8 \\
\hline 7. & Num. H-bond donors & 3 & 1 & 3 & 0 & 1 \\
\hline 8. & Molar Refractivity & - & 97.27 & 52.81 & 77.14 & 120.37 \\
\hline 9. & $\begin{array}{l}\text { Topological polar surface } \\
\text { area }\left(\AA^{2}\right)\end{array}$ & - & 168.31 & 134.55 & 60.44 & 91.29 \\
\hline 10. & Solubility (mg/ml) & 2.18 & 30.6 & 46.2 & 0.0894 & 0.0129 \\
\hline 11. & Solubility Class & Soluble & $\begin{array}{l}\text { Very } \\
\text { soluble }\end{array}$ & $\begin{array}{l}\text { Very } \\
\text { soluble }\end{array}$ & Soluble & $\begin{array}{l}\text { Moderately } \\
\text { soluble }\end{array}$ \\
\hline
\end{tabular}

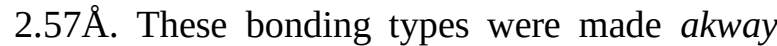
bark may assign Fe ion to the human cell body or receive Fe ion. As a result, low molecular weight complex antioxidant which conforms between $\mathrm{Fe}$ (also $\mathrm{Cu}$ and $\mathrm{Ni}$ ) and aromatic compound of akway bark was assigned as a free radical scavenger. The metals were played as a central atom and aromatic compounds (Table 1) acted as a ligand [11, 14, 24]. A metal complex compound has a strong antioxidant capacity compared to a single compound. Complex compounds with an electron group and metal transition as central atom were performed as electron transfer regulators. Free radical was released or received an electron from central complex compound ion without conforming to a radical complex. Besides, the single compound such as flavonoid, electron discharging to free radical would generate a phenoxy radical. It would be over if the electron met other radical electrons by phenoxy radical termination. Metal ions, like $\mathrm{Fe}^{2+}$ and $\mathrm{Fe}^{3+}$, will only refine the magnetic properties of complex compound from paramagnetic to diamagnetic conversely. It includes the electron transfer mechanism of hemoglobin [25].

Potential therapeutic based on pharmacological and pharmaceutical sciences were interestingly discussed, especially to modulate the levels of endogenous free radicals by molecules [26]. Reactive oxygen species (ROS), naturally, be products of cell metabolism. They may arrange a beneficial/deleterious character, depending on concentration and generation mode. ROS has been identified as a critical pathogenic element for diseases. On the other hand, the investigation of novel free radical scavenger molecules may promote the therapeutic agents for preventing and recuperating the diseases.

Low molecular weight complexes of transition metals binding to organic or natural components are identified as pharmaceutical agents $[26,11$, 14]. $\mathrm{Fe}, \mathrm{Co}, \mathrm{Ni}, \mathrm{Mg}, \mathrm{Ca}, \mathrm{Cu}, \mathrm{Zn}$, and $\mathrm{Cr}$ are required to maintain the health and sustainability of the human body because most critical biological functions in humans depend on their presence and their inadequacy may induce any diseases [27]. The body cell needs iron to synthesize oxygen transport proteins (myoglobin and hemoglobin) and for the conformation of heme enzymes and others involved in electron transfer and reductionoxidation mechanisms [28].

Swiss ADME made pharmacokinetic properties prediction. Based on Table 2, there were physicochemical and solubility of molecular formula which showed that akway bark is water-soluble. Estimating the aqueous solubility was done by measuring formula(s) directly from its structure. It was meant the akway bark might be a therapeutic agent [21]. The novel of molecular formula of akway bark as herbal medicine becomes complete with this study. The study of akway is limited to antibacterial activity and essential oil characterizations [5, 29]. Identifying molecular formula and predicting pharmacokinetic properties of akway 
bark would contribute an insight to further research.

\section{Conclusion}

Akway bark as a herbal medicine has five molecular formulas analyzed by UPLC-TOF-MS and their capability to bind to Fe ions as a complex. The binding of Fe and akway's formula are donor and acceptor metals. Therefore, the pharmacokinetic properties showed that akway bark-Fe has capability to aqueous soluble so it could be a novel pharmaceutical agent. So, they could be free radical scavengers based on low molecular weight antioxidants.

\section{References}

1. Santos-Sánchez NF, Salas-Coronado R, Villanueva-Cañongo C, Hernández-Carlos B (2019) Antioxidant Compounds and Their Antioxidant Mechanism. Intech Open: 1-28. doi: 10.5772/intechopen.85270.

2. Grammenandi K, Kyriazi M, Katsarou-Katsari A et al. (2016) Low-Molecular-Weight Hydrophilic and Lipophilic Antioxidants in Nonmelanoma Skin Carcinomas and Adjacent Normal-Looking Skin. Skin Pharmacol Physiol 2016 (29): 324-331. doi: 10.1159/000453456.

3. Saljoughian M (2008) An Overview of Antioxidants. US Pharm. 33 (10): HS-22-HS-28.

4. Shahidi F, Ambigaipalan P (2015) Phenolics and polyphenolics in foods, beverages and spices: Antioxidant activity and health effects - A review, Journal of Functional Foods 18 (Part B): 820-897. doi: 10.1016/j.jff.2015.06.018.

5. Cepeda GN, Lisangan MM, Silamba I (2019) Aktivitas Antibakteri Minyak Atsiri Kulit Kayu Akway (Drimys piperita Hook. f.) pada Beberapa Tingkat Konsentrasi, Keasaman $(\mathrm{pH})$ dan Kandungan Garam. Jurnal Aplikasi Teknologi Pangan 8 (4): 149-154. 10.17728/jatp.4692

6. Hutasoit H, Santjojo DJDH, Sumitro S B, Widjanarko S B (2019) Investigation of Paramagnetic Character in the Complex of Akway Bark (Drimys piperita Hook f.) as a Radical Scavenger. In Proceedings of the 2nd International Conference on Biosciences and Medical Engineering (ICBME2019) AIP Conference Proceedings 2155: 020052-1-020052-7. doi: 10.1063/1.5125556.

7. Parubak AS (2013) Senyawa flavonoid yang bersifat antibakteri dari akway (Drimys becariana. Gibbs) Chem. Prog. 6 (1): 34-37.

8. Ma F, Cui Q, Bai G (2019) Combining UPLC/Q-TOFMS/MS with Biological Evaluation for NF-kB Inhibitors in Uyghur Medicine Althaea rosea Flowers. Frontiers in Plant Science 1975: 1 - 9. doi: 10.3389/fpls.2018.01975.

9. Xu M, Shao Q, Ye S et al. (2017) Simultaneous extraction and identification of phenolic compounds in Anoectochilus roxburghii using microwave-assisted extraction combined with UPLC-Q-TOF-MS/MS and their antioxidant activities. Frontiers in Plant Science 1474: 1 11. doi :10.3389/fpls.2017.01474.

10. Ye T, Hao YH, Yu L et al. (2017) A simple, rapid method for determination of melatonin in plant tissues by UPLC Coupled with high resolution orbitrap mass spectrometry. Frontiers in Plant Science 64: 1 - 10. doi :10.3389/fpls.2017.00064.

11. Widyarti S, Kamaruddin M, Aristyani S et al. (2019) Bioinorganic Chemistry and Computational Study of Herbal Medicine to Treatment of Tuberculosis. Intech Open: 1-20. doi: 10.5772/intechopen.90155.

12. Sumitro SB, Sukmaningsih AASA (2018) Herbal medicine, radical scavenger and metal detoxification: Bioinorganic, complexity and nano science perspectives. IOP Conference Series: Earth and Environmental Science 130:012003. doi: 10.1088/17551315/130/1/012003.

13. Sukmaningsih AASA, Permana S, Santjojo DJDH et al. (2018) Investigating natural transition metal coordination anthocyanin complex in java plum (Syzygium cumini) fruit as free radical scavenging Rasayan Journal


10.31788/RJC.2018.1133047

14. Engwa GA (2018) Free radicals and the role of plant phytochemicals as antioxidants against oxidative stress-related diseases. In: Phytochemicals - Source of Antioxidants and Role in Disease Prevention. doi: 10.5772/intechopen.76719.

15. Zielinska D, Zielinski H. (2009) Low molecular weight antioxiants and other biologically active components of buckwheat seeds. The European Journal of Plant Science and Biotechnology 3 (1): 29-38.

16. Deng S, West BJ, Jensen CJ (2013) UPLC-TOF-MS Characterization and Identification of Bioactive Iridoids in Cornus mas Fruit. Journal of Analytical Methods in Chemistry 710972. doi: 10.1155/2013/710972.

17. Pérez S, Tvaroška I (2014). Carbohydrate-protein interactions: molecular modeling insights. Advances in Carbohydrate Chemistry and Biochemistry (71): 9-136. doi: 10.1016/B978-0-12-800128-8.00001-7.

18. Jayanti GE, Widyarti S, Sabarudin A, Sumitro, SB (2018) Egg White Albumin Form Complex With Aspirin And Caffeine And Its Role As Free Radical Scavenger. Asian Journal of Pharmaceutical and Clinical Research, 11(7) : 340-344. doi: 10.22159/ajpcr.2018.v11i7.25440.

19. Wibowo S, Widyarti S, Sabarudin A et al. (2019). The role of astaxanthin compared with metformin in preventing glycated human serum albumin from possible unfolding: a molecular dynamic study. Asian Journal of Pharmaceutical and Clinical Research 12 (9): 276-282. doi: 10.22159/ajpcr.2019.v12i9.34617.

20. Feinstein WP, Brylinski M (2015) Calculating an optimal box size for ligand docking and virtual screening against experimental and predicted binding pockets. Journal of Cheminformatics 7 (18) doi: 10.1186/s13321015-0067-5.

21. Daina A, Michielin O, Zoete V (2017) SwissADME: a free web tool to evaluate pharmacokinetics, drug-likeness and medicinal chemistry friendliness of small molecules. Scientific Reports 7 (42717). doi: 10.1038/srep42717

22. Gondokesumo ME, Pardjianto B, Sumitro SB et al. (2019) Xanthones Analysis and Antioxidant Activity Analysis (Applying ESR) of Six Different Maturity Levels of Mangosteen Rind Extract (Garcinia mangostana Linn.). Pharmacognosy Journal 11 (1): 369-373. doi : 10.5530/pj.2019.11.56 
23. Wang L, Cui Q, Hou Y et al. (2013) An integrated strategy of ultra-high-performance liquid chromatography/quadrupole-time-of-flight mass spectrometry and virtual screening for the identification of $\alpha$-glucosidase inhibitors in acarviostatin-containing complex. Journal of Chromatography A 1319: 88-96. doi: 10.1016/j.chroma.2013.10.035

24. Jabeen E, Janjua NK, Ahmed S et al. (2017) Radical scavenging propensity of $\mathrm{Cu}^{2+}, \mathrm{Fe}^{3+}$ complexes of flavonoids and in-vivo radical scavenging by $\mathrm{Fe}^{3+-}$ primuletin. Spectrochimica acta. Part A, Molecular and bioMolecular Spectroscopy 171: 432-438. doi: 10.1016/j.saa.2016.08.035

25. Bren KL, EisenbergR, Gray H B (2015) Discovery of the magnetic behavior of hemoglobin: A beginning of bioinorganic chemistry. Proceedings of the National Academy of Sciences 112(43): doi:13123. 10.1073/pnas.
26. Bencini A, Faili P, Valtancoli, B, Bani, D (2010) Low Molecular Weight Compounds with Transition Metals as Free Radical Scavengers and Novel Therapeutic Agents. Cardiovascular \& Hematological Agents in Medicinal $\begin{array}{llll}\text { Chemistry } & 8 & \text { (3): } & 128-146 .\end{array}$ $10.2174 / 187152510791698389$

27. Gupta SP (2018) Roles of metals in human health MOJ Bioorganic \& Organic Chemistry. 2(5): 221-224. doi: 10.15406/mojboc.2018.02.00085

28. Abbaspour N, Hurrell R, Kelishadi R (2014) Review on iron and its importance for human health. Journal of research in medical sciences: the official journal of Isfahan University of Medical Sciences 19(2): 164-174.

29. Cepeda GN, Santoso B B, Lisangan M M, Silamba I (2011) Komposisi kimia minyak atsiri kulit kayu akway (Drimys piperita Hook. F). Bionatura - Jurnal Ilmu-Ilmu Hayati dan Fisik 13 (2): 117-123. 
This page is intentionally left blank. 